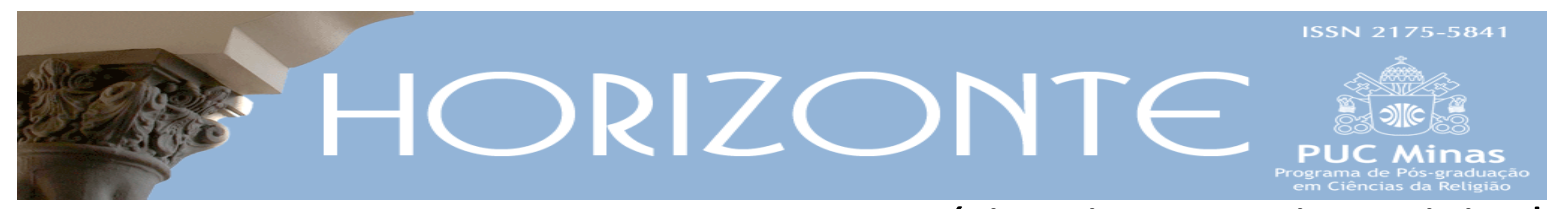

Temática Livre - Artigo original

DOI - 10.5752/P.2175-5841.2015v13n38p907

\title{
Um segredo escondido e revelado entre fios: Jz 16,4-22
}

\section{A secret hidden and revealed in the threads: Jg 16:4-22}

\author{
Paulo Jackson Nóbrega de Sousa*
}

\begin{abstract}
Resumo
As estórias do ciclo de Sansão estão bastante enraizadas no imaginário popular. Utilizando a Análise Narrativa em diálogo com o Método Histórico-Literário, este artigo pretende explicar exegeticamente um relato presente em Jz 16,4-22. Trava-se uma relação dinâmica e promissora entre conteúdo e forma, entre a beleza estética e a mensagem teológica de um tecido literário. Parte-se da análise morfossintática verbal da narrativa e do discurso direto. Estuda-se a cadeia narrativa, a noção de tempo e o esquema de repetição em " $3+1$ ", para, finalmente, se definir a trama e compreender as ações dos personagens em cada cena. Para além dos fios que se entrecruzam, a perícope nos convida a contemplar um belo e unitário tecido. Dalila, paga pelos filisteus, pretende descobrir o segredo da força de Sansão com o objetivo de dominá-lo e subjugá-lo. Depois de três tentativas falidas, finalmente consegue realizar o seu intento. $O$ segredo é escondido e revelado entre fios, que se tornam símbolo da vida humana e de modo particular da história de Israel que desconhece a origem de sua força: Deus.
\end{abstract}

Palavras-chave: Sansão; Dalila; análise narrativa; segredo; fios.

\begin{abstract}
The stories from the Samson cycle are very well known in the popular imagination. Utilizing Narrative Analysis in dialogue with the Literary-Historical Method, this article seeks to explain exegetically the story present in Judges 16:4-22. A dynamic and promising relationship between content and form, aesthetic beauty and theological message is established by a fine literary threading. The study begins with a morphosyntactic verbal analysis of the narrative and direct speech, studying, in turn, the narrative chain, the notion of time and the repetitive scheme of " $3+1$ " in order to define the plot and understand the action of the characters in each scene. In addition to the threads that are interwoven, the pericope invites us to contemplate the beautiful and unified tissue. Delilah, paid by the Philistines, intends to discover the secret of Samson's force with the objective to subdue and humiliate him. After three failed attempts, she finally accomplishes her purpose. The secret is hidden and revealed in the "threads" that become a symbol of human life and, in a particular way, of the history of Israel that fails to recognize the origin of its strength, that is to say, God.
\end{abstract}

Keywords: Samson; Delilah; narrative analysis; secret; threads.

Artigo recebido em 09 dez. 2014 e aprovado em 23 de junho de 2015.

* Doutor em Teologia. Professor do Departamento de Teologia da Faculdade Jesuíta de Filosofia e Teologia da Pontifícia Universidade Católica de Minas Gerais. País de origem: Brasil. E-mail: pajanosousa@hotmail.com.

Horizonte, Belo Horizonte, v. 13, n. 38, p. 907-940, abr./jun 2015 - ISSN 2175-5841 


\section{Introdução}

As estórias do ciclo de Sansão ( $\mathrm{Jz} 13-16)$ estão bastante enraizadas no imaginário popular e nas artes. Só para permanecer num exemplo, é inegável a importância e a contribuição às artes da Ópera Sansão e Dalila de Camille SaintSaëns (1877). Nos últimos anos, no âmbito dos estudos bíblicos, surgiram novas oportunidades de diálogo e colaboração entre o Método Histórico-Crítico e métodos de caráter sincrônico. Muitos exegetas passaram cada vez mais a usá-los na análise de textos das escrituras judaico-cristãs, especialmente aqueles que reservam um papel mais dinâmico e ativo ao leitor. Aliás, o próprio Método Histórico-Crítico passou por profundas reformulações, incorporando elementos novos. Assim, trava-se uma relação mais promissora entre conteúdo e forma, entre a beleza estética e a mensagem de um tecido literário.

A Análise Narrativa vem se firmando como um destes métodos sincrônicos com resultados mais expressivos. Por isso, em cooperação com a perspectiva histórico-literária, nós a utilizamos para este estudo sobre uma perícope do ciclo de Sansão: Jz 16,4-22. Depois da discussão de algumas questões introdutórias relativas à delimitação do texto, tradução e crítica textual, estudaremos, a partir da sintaxe verbal, a cadeia narrativa, a função dos discursos e a noção de tempo na narrativa. Finalmente, refletiremos sobre a tipologia da trama e a divisão da perícope em cenas. Na conclusão, teremos a oportunidade de propor uma visão mais sintética da perícope a partir de seu tema e função teológica.

\section{Preliminares}

\subsection{Delimitação do Texto}

O início da perícope é bem delimitado por meio de elementos formais e de conteúdo. A perícope anterior $(\mathrm{Jz} 16,1-3)$ relata a visita de Sansão a uma prostituta 
de Gaza. Os habitantes da cidade armam uma emboscada para prendê-lo, mas ele, levantando-se no meio da noite, arranca as portas da cidade com as suas trancas e as carrega até o monte próximo de Hebrom. O versículo 4 inicia com um wayeĥ ("e aconteceu que"), seguido de duas indicações: temporal ('ahăărê-kêen - "depois disto") e espacial (de Gaza ao Vale do Soreq). A indicação temporal provavelmente refere-se ao episódio anterior (visita a Gaza) ou pode ser uma forma de vinculação com os dois episódios anteriores nos quais está envolvida uma mulher: a mulher de Timnah (14,1) e a prostituta de Gaza (16,1) (CRENSHAW, 1978, p. 70-71). O valor de wayehî no v. 4 é bastante claro: marca, como um "sinal macrossintático", o início de uma narração (WALTKE; O’CONNOR, 1990, § 3.3.4d).

Se o início da perícope é perfeitamente delimitável, não há a mesma clareza em relação ao final. Tomamos por base a conclusão no v. 22. Do ponto de vista formal, o v. 23 é marcado pela sintaxe disjuntiva e pela construção $\mathrm{X}+$ qatal (w'sarnê pelištîm ne’ěsph - "então, os príncipes do filisteus se ajuntaram”), um dos sinais de início da narração de uma nova ação. A temática, em algum sentido, continua a mesma: até o v. 22, o projeto dos filisteus é capturar e humilhar Sansão; a partir do v. 23, inicia a narração da grande celebração que os filisteus fazem ao seu deus, cuja motivação é claramente apresentada: wayyōmer $r u$ nātan 'ělōhênû beyādēnû 'èt šimšôn - "E diziam: 'nosso deus nos deu Sansão em nossa mão"'. Porém, o ambiente, as ações e o léxico mudam substancialmente. Em relação aos personagens, aos chefes dos filisteus é acrescentado o povo ('am) que se alegra e faz festa. Todavia, a informação que nos é dada no v. 22 - o crescimento do cabelo - funciona como ponte de conexão em vista do desenlace final da trama (v. 30), ou seja, há uma nova concentração de suspense que espera um desenvolvimento da trama e uma conclusão. 


\subsection{Crítica Textual}

O texto da perícope registra alguns problemas de Crítica Textual ${ }^{1}$. Será apresentado apenas o mais expressivo de acordo com o aparato crítico da Biblia Hebraica Stuttgartensia (BHS). Do final do v. 13 até a metade do v. 14 há uma lacuna no texto hebraico. Barthélemy (1982, p. 112) o cita como um caso típico de homoteleuton, cuja palavra-moldura é hammassāket (vv. 13 e 14). Para a restauração, seguimos a proposta de Moore, citado por Boling (1975, p. 249), baseada no texto de tipo B (Códice Vaticano) da $\mathrm{LXX}^{2}$ : “... e se tu as fixares na parede com um pino, então serei fraco como um dos homens. Enquanto ele estava dormindo, Dalila tomou as sete tranças de sua cabeça e as teceu com a urdidura...”.

\section{Análise da Sintaxe Verbal: a cadeia narrativa}

Este tópico do nosso estudo tenta compreender a relação entre forma verbal (morfologia) e função da mesma na frase (sintaxe), isto é, como a forma verbal utilizada determina a sequência e o retrocesso, as articulações e as rupturas no texto, e que tipo de discurso surge a partir do uso de tais formas verbais escolhidas. J. van der Merwe (1994, p. 23) propõe duas diferenciações que nos ajudam a compreender a sintaxe verbal hebraica na prosa: a primeira, entre narração e diálogo; a segunda, entre linha principal e linha secundária da comunicação. A perícope estudada apresenta uma grande riqueza, já que se registram narração e discurso direto, cadeia narrativa e ruptura, linha principal e secundária da comunicação, sentença verbal e nominal, sentença nominal simples e complexa.

\footnotetext{
${ }^{1}$ No v. 18, há um caso de Qere/Ketib. Muitos manuscritos e a maioria das versões leem o Qere ao posto do Ketib. Propomos, portanto, ler lî ("... ele fez conhecer 'a mim' todo o seu coração"). Ainda no v. 18, o weqatal w eâlû ("e subirão") deve ser corrigido, seguindo vários manuscritos e a LXX (kai, + aoristo), por um wayyiqtol (wayya'ălû - "e subiram"). No v. 19, há problemas em relação ao sujeito

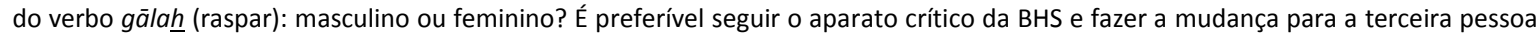
masculina singular (way ${ }^{e}$ gallah $)$, seguindo um manuscrito hebraico e alguns manuscritos gregos da LXX.

${ }^{2} \mathrm{O}$ aparato crítico da BHS propõe a restauração a partir do texto do Códice Alexandrino (A).
} 
$\mathrm{Na}$ sintaxe hebraica, o wayyiqtol é a forma verbal por excelência da narração, aparecendo numa posição inicial e desenvolvendo-se por meio de uma cadeia. Assim, a narração "cresce" e, por meio dos seus relevos e tensões, logra o seu objetivo. Inicialmente, separemos narração e discurso direto. O discurso direto aparece nos seguintes versículos:

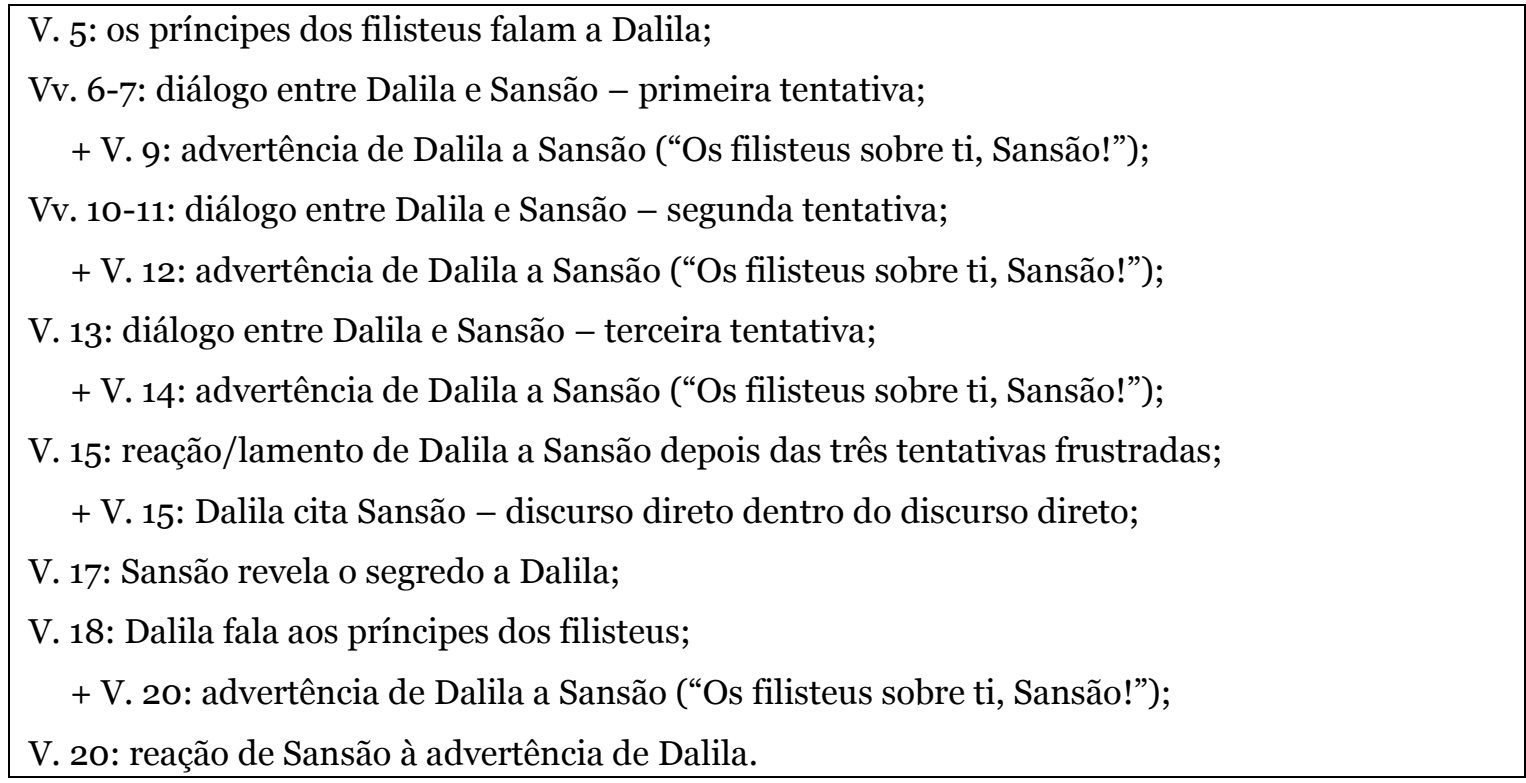

É notório, a partir deste inventário, que o discurso direto ocupa uma grande parte da perícope. Este, exceto no v. 18, é sempre introduzido pelo wayyiqtol do verbo 'āmar (dizer)3. A sequência narrativa caminha, portanto, em meio ao discurso direto, costurando o tecido literário e fazendo-o avançar. Há alguns versículos onde a cadeia narrativa é particularmente visível. Eis a sequência do v. 12: tomou cordas novas $>e$ o amarrou $>e$ disse $>E$ ele as arrebentou. Mais clara ainda é a cadeia do v. 19: Ela o [Sansão] fez dormir > ela chamou um homem $>e$ este raspou > e ela começou a subjugá-lo > e retirou-se dele a sua força.

${ }^{3} 8$ vezes para Dalila (3fs); 5 vezes para Sansão (3ms); e 1 vez para os chefes dos filisteus (3mp). 
As frases anteriores estão todas no mesmo nível da cadeia narrativa. Bem diverso é quando observamos o uso do qatal na narração. Investigando o uso do

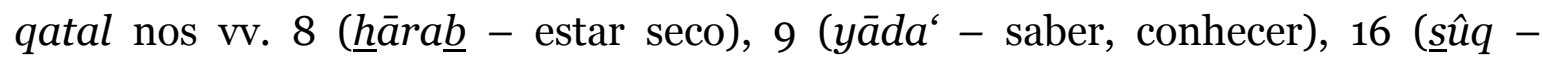
pressionar, constranger), 18 (nāgad - contar, declarar), 20 (yāda' - saber, conhecer; e sûr - aprisionar, amarrar) e 22 (gāla $\underline{h}$ - raspar), percebe-se que, na narração, essa forma verbal tem a função retrospectiva, de comentário, esclarecimento ou recuperação de algum aspecto da ação principal já apresentada na sequência de wayyiqtol. O qatal, portanto, não faz a cadeia narrativa avançar. Igualmente, no discurso direto (vv. 7.10.11.13.15.17.18), percebe-se o fenômeno retrospectivo do qatal, bastante claro nos vv. 13 e 17-18. No v. 13, por causa da explícita partícula 'ad-hēnnāh (até agora) que reassume todo o processo anterior; e nos vv. 17-18: aquilo que é narrado com um wayyiqtol no v. 17 (wayyagged-lāh 'et-kol-libbô - linha principal da narração), é retomado secundariamente por um qatal, no v. 18, na narração (wattēre' delîlāh kî-higgîd lāh 'et-kol-libbô) e no discurso direto ( ‘ălû happa 'am kî̀-higgîd lî'et-kol-libbô).

Enquanto o wayyiqtol é a forma básica para a narração, fazendo evoluir a sequência narrativa, no discurso direto aparece frequentemente o yiqtol (12x) e o weqatal (8x). Na perícope, aparece: yiqtol (+ ’im) com sintaxe condicional (vv. 7 ['āsar]. 11 ['āsar]. 13 ['ārag]); yiqtol que segue uma forma imperativa: vv. 6.10.13 ('āsar - sempre quando Dalila fala a Sansão) e v. 5 (yākal - quando os chefes dos filisteus falam a Dalila); o yiqtol com o valor de um simples futuro (v. 5 [nātan]; v. 20 [yās $\bar{a}$ ' e $n \bar{a}$ 'ar]); nos vv. 9 [nātaq] e 15 ['āmar]. O yiqtol tem valor habitual ou frequentativo, sendo traduzido com um presente ou um imperfeito na língua portuguesa.

O weqatal (cf. LONGACRE, 1994, p. 50-98) é outra forma muito frequente no discurso direto4: nos vv. 7. 11 e 17 [hāyāh e $\underline{h a} \bar{a} \bar{a} h]$. Quase como uma fórmula fixa, o weqatal tem nuance preditiva ou futura. Ainda no v. 17 [sûr] tem valor de

\footnotetext{
${ }^{4}$ Não está presente no v. 13 porque é restaurado segundo o texto da LXX.
} 
futuro5; caso especial é o v. 5 ['āsar], onde o weqatal segue um yiqtol com valor modal. Ainda no discurso direto são comuns as formas volitivas (verbo no imperativo): v. 5: pedido/comando dos chefes dos filisteus a Dalila; v. 6: primeiro pedido de Dalila a Sansão; v. 10: segundo pedido de Dalila a Sansão; v. 13: terceiro pedido de Dalila a Sansão; v. 18: Dalila convoca os chefes dos filisteus ${ }^{6}$.

Resta-nos ainda uma palavra sobre o uso de wayehî e sobre algumas frases construídas com particípio. Certamente os dois momentos onde aparece mais explicitamente a ruptura na cadeia narrativa são o v. 9 e o v. 12. Depois de uma sequência de wayyiqtol do v. 8 (wayya ălû > watta'asrēhû: "Os príncipes dos filisteus levaram a ela sete cordas... e ela o amarrou com elas"), aparece uma informação no v. 9, construída com sintaxe disjuntiva, que quebra a sequência: "Ora, havia alguém em tocaia alojado em seu quarto". O mesmo fenômeno é percebido no v. 12: depois da sequência de wayyiqtol (wattiqqah > watta'asrēhû > wattō'mer: "Dalila tomou cordas novas e o amarrou com elas e disse..."), surge a cisão da cadeia ( $w^{e} h \bar{a}$ 'ōrēb yōšē $\underline{b}$ behāder: "Ora, havia algum tocaia alojado em seu quarto”). Em ambos os casos, a narrativa continua posteriormente, fazendo gancho com a cadeia anterior à quebra: wayenattēq ("E ele arrebentou”). Tais fissuras no texto têm exatamente a função de criar relevo, certa pausa dramática, para que o texto não escorra completamente retilíneo7.

Como já indicado acima, o wayehî tem uma função importante na narração exatamente porque é um sinal para introduzir ou marcar pontos relevantes dentro de um relato. Por outro lado, muitas vezes o wayehî introduz uma circunstância temporal anterior à ação principal (NICCACCI, 1994, § 30). No v. 4, encontramos o

\footnotetext{
${ }^{5}$ É muito reveladora a informação que é acrescentada neste versículo: diferentemente dos versículos anteriores (vv. 7 e 11 - “... me enfraquecerei e serei como um homem qualquer") e do texto da LXX usado para restaurar o TM, somente quando Sansão revela a verdade do seu segredo, falando explicitamente de "navalha" ou de "raspar o cabelo" (v. 17) é que vem acrescentado o tema da "força".

${ }^{6} \mathrm{O}$ mais curioso é perceber, no texto, que a resposta verdadeira de Sansão não é posterior a uma forma verbal imperativa da parte de Dalila. Nos vv. 6, 10 e 13 (forma verbal imperativa) as respostas de Sansão são sempre falsas.

${ }^{7}$ Niccacci assim sintetiza a função das rupturas: A quebra da cadeia narrativa principal "signals a break in the chain for a special purpose, such as to stress a detail of the main information, or to express the writer's comment on his story, or to restage the story and introduce a new character or some other background. Alternation from one set to another provides relief and displays the writer's strategy of communication" (1994, p. 131).
} 
primeiro caso. $\mathrm{O}$ wayehî introduz uma circunstância temporal acompanhada da expressão temporal 'ah̆ărê-kêen (depois disto) na prótase, tendo na apódose um wayyiqtol. Poderíamos propor a seguinte tradução: "Ora, depois disso [prótase], ele [Sansão] amou uma mulher no Vale de Soreq" [apódose]. Assim começa a cadeia narrativa, tendo como elemento primordial o verbo 'āha $\underline{b}$ (amar). Porém, logo em seguida, aparece a primeira quebra da sequência narrativa com uma frase nominal: "O nome dela [era] Dalila". Neste momento da "exposição", Dalila é apresentada, já que se trata do único personagem novo no relato.

Um segundo momento do uso de wayehî é o v. 16. Esse versículo tem uma estrutura um pouco mais complexa, sobretudo para se determinar onde começa a apódose. Por outro lado, o verbo 'ālas no piel (constranger, pressionar fortemente) é um hapax legomenon, o que faz um pouco mais difícil a compreensão. Contudo, o contexto é bastante claro. Vejamos: "Ora, como ela o pressionava com suas palavras todos os dias, então ela o constrangeu e sua alma se angustiou até a morte". A circunstância temporal é bastante clara, pois é construída com dois marcadores na prótase: $k \hat{\imath}$ + verbo finito e a expressão temporal kol-hayyāmîm (todos os dias). A apódose é construída com dois wayyiqtol, porém, com um particular: o sujeito do primeiro é Dalila e do segundo Sansão. O v. 16 marca um momento importante na narração, pois reassume toda a carga de pressão exercida por Dalila sobre Sansão. Na verdade, aproxima-se o momento do "turning-point". Sansão chega ao fundo do poço na sua capacidade de resistência. Tal processo deságua no v. 17 com a revelação do segredo.

O terceiro uso do wayehî está na última parte do v. 21, que deve ser associada com o v. 22. No desenlace final da perícope, é narrado o processo de humilhação de Sansão por parte dos filisteus e sua situação conclusiva. Eis a construção: "Ora, ele girava o moinho na prisão e o cabelo de sua cabeça começou a crescer como quando tinha sido raspado". A construção é bastante simples: way ${ }^{e} \hat{\imath}+$ particípio (na esfera do passado e com aspecto durativo) (cf. JOÜON; MURAOKA, 2011, §121, f). Eles estão associados ao v. 22 que lhes dá sequência com um wayyiqtol. Mais uma vez o wayehî marca um momento importante no 
interior do relato: a conclusão deste segmento narrativo. Por causa do aspecto durativo do particípio, há certa relação de concomitância entre esse final do v. 21 e o v. 22.

\section{A Noção de Tempo na Perícope}

\subsection{Mudanças de ritmo e de ordem na arte de narrar}

Uma distinção fundamental em Análise Narrativa é esta entre "estória" (story) e "discurso" (discourse) $)^{8}$ e, associada a esta, aquela entre o "tempo narrado" e o "tempo da narração" (SKA, 1990, p. 7-8; 113-114). Em palavras simples, podemos dizer que "discurso" é o texto, enquanto "estória" é aquilo que está sendo narrado, muitas vezes, nas entrelinhas, nos silêncios e lacunas entre as palavras e frases do texto.

Quando lemos correntemente o texto, quase que num exercício inconsciente, preenchemos as possíveis lacunas que o autor deixa sob a responsabilidade do leitor. Esse processo é extremamente significativo, pois revela a participação ativa do leitor na tarefa de construção do tecido literário. O sentido vai sendo engendrado em sendas marcadas pela participação e pela dinamicidade, entre as informações dadas pelo narrador, pelos discursos diretos e pela participação efetiva do leitor. O autor, em muitos casos, até por um desejo de "economia" não se preocupa com a narração de alguns detalhes que não são essenciais para a construção da trama (SKA, 1995, p. 64-65). Na perícope, podemos perceber alguns desses fenômenos, senão vejamos:

\footnotetext{
${ }^{8}$ A propósito, Ska (1990, p. 5-6) assim sintetiza as diferenciações complexas dos termos devido ao uso em várias línguas, por vários autores, e, às vezes, com semânticas diversas: “...the 'discourse' is the concrete narrative, in its actual shape, that the reader has before his eyes, and the 'story' is an abstract reconstruction in which the reader (re)places the elements of the 'discourse' according to a logical and chronological order and supplies what is missing".
} 
a. Nos vv. 4 e 5, depois de introduzir um novo personagem (Dalila) e falar do amor entre ela e Sansão, vem-nos uma informação da cadeia narrativa em wayyiqtol: os chefes dos filisteus sobem até Dalila e lhe propõem a descoberta do segredo de Sansão. O texto não se preocupa em alongar-se e responder algumas perguntas, deixando-as a cargo do leitor: Como surgiu o amor entre Sansão e Dalila? Em que circunstâncias ele a conheceu? Quanto tempo passou até que os chefes dos filisteus ficassem sabendo do namoro dos dois? Como eles souberam? Quanto tempo depois e baseados em quais indícios eles resolveram fazer a proposta a Dalila? Poderíamos acrescentar outras perguntas à lista.

b. Entre os vv. 5 e 6 repete-se o mesmo fenômeno. Os chefes dos filisteus fazem a proposta a Dalila; ela não lhes dá nenhuma resposta. Imediatamente, Dalila já está falando com Sansão. O que Dalila faz entre o pedido dos filisteus e o encontro com Sansão? O narrador tem uma grande pressa para pôr juntos Sansão e Dalila. Logo Dalila inicia a primeira tentativa para descobrir o segredo de Sansão: este é o ponto fulcral do relato. Por isso, o autor não se preocupa de, no "discurso", descrever a resposta de Dalila aos filisteus; ou quanto tempo depois Dalila encontrou Sansão; onde o encontrou; etc. O leitor, na verdade, reconstrói a "estória" em sua mente à medida que lê. Claramente entre os vv. 4 e 6 o "tempo da narração" - as palavras e frases utilizadas - é bem mais curto do que o "tempo narrado", isto é, o tempo cronológico que separa os acontecimentos.

c. A perícope é construída cuidadosamente conservando a dinâmica entre narração e diálogo. Quando iniciam os discursos diretos, a equação de tempo muda. Enquanto na narração, muito mais frequentemente, o "tempo narrado" é maior que o "tempo da narração", nos diálogos existe certa equivalência entre os dois tempos, pois o texto registra precisamente o processo da fala, o desenrolar da conversação. Assim podemos perceber nos vv. 6-7.10-11.13-14 (LXX).

d. As quatro tentativas para descobrir o segredo de Sansão e dominá-lo seguem certo esquema: pedido de Dalila > resposta de Sansão > preparativos > "Os filisteus sobre ti, Sansão!" > reação de Sansão. No momento, ocupar-nos-emos 
da seção "preparativos" para tentar perceber a mudança de tempo entre as quatro situações. Esquematicamente, podemos assim resumir os três primeiros preparativos à captura de Sansão9: ação dos príncipes dos filisteus (v. 8.-.-); ação de Dalila (vv. 8.12.13 [LXX]); presença dos tocaias (vv. 8.1210.-).

Percebe-se que há um processo decrescente nos três primeiros preparativos: no primeiro, os três elementos estão presentes (a ação dos chefes dos filisteus, a ação de Dalila e a notícia da presença de alguém em tocaia); no segundo, dois elementos; e no terceiro, somente um. Tal processo revela a pressa do narrador evitando alongar-se em detalhes que o leitor pode supor ou que não são essenciais para o desenlace da trama - para chegar ao preparativo da segunda etapa, isto é, da quarta tentativa (vv. 18-19). Novamente aqui o processo é narrado detalhadamente, retornando os três elementos já descritos no esquema. Há uma desaceleração do ritmo da narração. Dalila, ao perceber que Sansão disse toda a verdade, chama os chefes dos filisteus - que levam consigo o dinheiro -, faz Sansão dormir em seus joelhos e chama um homem para que raspe as suas tranças.

Outro elemento importante para perceber a relação entre o "tempo narrado" e o "tempo da narração" é a costura entre uma tentativa e outra de capturar Sansão. O escritor poderia resumir com uma frase informativa que Dalila tentou por três vezes descobrir o segredo de Sansão. Assim o "tempo narrado" seria extremamente maior que o "tempo da narração". Mas, quanto tempo passou entre uma tentativa e outra? Não se sabe, porém com certeza uma tentativa não poderia ter sido imediatamente sucessiva à outra. Pode-se imaginar certa distância psíquica e cronológica entre uma tentativa e outra que não é minimamente acenada pelo narrador. Esses detalhes de menor importância não o preocupam. Todavia, em se tratando da última tentativa, há um sinal mais evidente de uma maior equivalência entre o "tempo da narração" e o "tempo narrado": embora não

\footnotetext{
${ }^{9}$ Os versículos, ou a falta deles, seguem a sequência das três tentativas.

${ }^{10} \mathrm{~A}$ informação é dada retrospectivamente, depois da advertência a Sansão.
} 
descrevendo em detalhes a maneira de proceder de Dalila, o narrador ao menos no v. 16 nos dá a seguinte informação: "E aconteceu que ela o pressionava com suas palavras todos os dias".

No final do v. 18 o autor nos dá a conhecer outra informação importante: "E subiram até ela os chefes dos filisteus e levaram o dinheiro em mãos". Ela é claramente uma antecipação do final do relato, pois os filisteus trazem o dinheiro mesmo antes de Sansão estar dominado. Por outro lado, revela-se a lacuna de uma informação secundária. Dalila, depois de trair Sansão, desaparece do relato. No "discurso" não mais se fala de Dalila ou do dinheiro; o leitor, contudo, na "estória" pode tranquilamente imaginar que ela recebeu a sua recompensa.

Certa mudança de ordem ou sequência aparece também no final do v. 19: Dalila, em tese, começa a oprimir Sansão quando ele ainda está dormindo. Igualmente, a constatação de que "a sua força se havia separado dele" é feita antes que ele tenha despertado, já que isso só acontece no v. 20 a partir da exclamação de Dalila.

\subsection{Entre narração e diálogo}

Quando temos o texto em nossas mãos pela primeira vez, imediatamente nos damos conta de que a perícope é construída com um entrelaçamento de narração e discurso direto, predominando, porém, o discurso direto. É de conhecimento geral a concretude da maneira hebraica de contar os fatos: a palavra é fato e ação.

Sem levar em conta as fórmulas fixas de início de um diálogo, a narração predomina na abertura da perícope para fazer a apresentação de Dalila e dizer da situação inicial de Sansão: ele ama uma mulher no Vale do Soreq. Depois retorna de maneira mais elaborada e extensa no final - do final do v. 18 até o v. 22, com duas breves interrupções - para expor o processo de derrota de Sansão e sua situação final. O miolo do relato é basicamente constituído de diálogos, conectados 
por pequenas emendas narrativas. Essa é a maneira característica de contar dos escritores hebraicos, isto é, são de uma tradição narrativa onde predomina o diálogo direto e a força da fala ${ }^{11}$.

Mas a que serve o modo narrativo? Ele tem um papel predominante na exposição, com uma ênfase para a apresentação dos nomes ou de características peculiares dos personagens. Devido às grandes dificuldades para a explicação etimológica, não entramos no mérito da questão do nome "Dalila". Tal ambiguidade na interpretação de sua etimologia talvez seja uma riqueza, já que conserva o mistério e a mescla de três características num único personagem ${ }^{12}$ : a sedutora (que flerta), a enigmática (a mulher da noite) e a traidora (aquela que indica). Porém, em geral, a exposição tem um efeito proléptico, isto é, antecipatório (SKA; SONNET; WÉNIN, 1999, p. 29-30). Outras vezes, as narrações revelam julgamentos morais da parte do narrador ou sentimentos e traços psicológicos dos personagens. Todavia, intercalando os diálogos, as narrações introduzem ações essenciais para o desenvolvimento da trama - que é o caso mais marcante na perícope -, ou dados acessórios, ou retomadas quase literalmente, de elementos já expressos no discurso direto (p. ex.: o v. 8 reassume o v. 7).

Por outro lado, por meio dos diálogos ${ }^{13}$, sobretudo, os personagens revelam sua identidade, seu caráter, sua capacidade de agir e reagir. Aqui se revela com toda pujança a força da palavra na maneira de narrar dos hebreus, baseada na "cena”, na ação dos personagens que falam e agem e fazem a trama crescer. Uma característica muito especial da narrativa hebraica na perícope é a presença de um discurso direto dentro de um discurso direto no v. 15. A informação dada pelo

\footnotetext{
${ }^{11}$ Cf. todo o capítulo IV de ALTER, 1990, p. 84-111.

${ }^{12}$ Com base numa raiz árabe (dallattum), Gray (1967, p. 356) defende a primeira proposta, a qual é seguida também por Boling (1975, p. 248) e por Crenshaw (1978, p. 18), que propõe a tradução "affectionate". Block (1999, p. 453-454) oferece uma boa síntese das diferentes propostas e, mesmo considerando a segunda possibilidade como a mais interessante (de lay eāh - noite), defende que, "etymologically, the most likely explanation relates the name to Arabic dalla, 'to flirt'". Com base numa raiz árabe, Lagrange (1903, p. 246) propõe a terceira explicação.

${ }^{13}$ Miller (1994, p. 199) nos dá uma contribuição importante no tocante à maneira de introduzir os discursos diretos: a) wayyō'mer sem combinação com outro verbo (vv. 6.7.9.20, etc.); b) wayyō'mer seguido de um outro verbo dicendi (v. 17); c) verbo finito + lē'mōr (v. 18). Aqui também se revela a riqueza dos diálogos na perícope, já que estão presentes as três formas clássicas de introdução de um discurso direto.
} 
narrador no v. 4 - “... ele amou uma mulher...” - é retomada por Dalila, porém posta na boca de Sansão, por isso o uso do verbo na primeira pessoa do singular. Um segundo detalhe importante é o monólogo interior de Sansão no v. 20. Aqui põe-se a problemática da interpretação do wayyōmer como "disse" ou "pensou”, que só o contexto pode resolver. Nesse caso concreto, somos mais propensos à segunda opção: o autor põe o leitor a nu diante do pensamento do personagem.

\subsection{A estrutura 3 + 1: uma repetição criativa}

Como já dito, o autor tem pressa e, por conseguinte, o "tempo narrado" é muito maior que o "tempo da narração". Se, por um lado, o critério da "economia" é tão presente nas narrativas bíblicas, por outro lado, o nosso texto é construído seguindo o modelo das repetições. Lendo com os olhos de um leitor moderno, temos dificuldade de compreender a função das repetições. Podemos imaginar que o narrador poderia somente com uma frase resumir as três tentativas e dizer algo como: "Dalila por três vezes tentou descobrir o segredo da força de Sansão e capturá-lo, mas por três vezes ele mentiu e conseguiu escapar”. A narração ganharia concisão, mas perderia em beleza e em força dramática. Tentemos, então, entender em que consiste e como funcionam as repetições.

Robert Alter (1990, p. 112-140; cf. também JONKER, 1996, p. 199) propõe uma tipologia das repetições que vai da "Leitwort" (palavra-chave) à "cena típica", passando pelo "motivo", pelo "tema" e pela "sequência de ações". Em relação à perícope estudada, trataremos das repetições de palavras-chave e da sequência de ações. Percebe-se imediatamente que, depois do verbo 'āmar (dizer), que serve de introdução aos diálogos, a raiz mais presente no trecho é 'sr (amarrar - 11x: vv. 5.6.7.8.10.11 [2x].12.13.21 [2x]). É muito sintomático o salto que faz a raiz 'sr: ocorre até o v. 13 e retorna somente no 21. Já se pode antecipar, portanto, que a preocupação fundamental na primeira parte da perícope e no final será descobrir como amarrar Sansão, daí a insistência de Dalila no uso do verbo ngd (narrar, contar), que aparece três vezes introduzindo as três primeiras tentativas (vv. 
6.10.13) de revelação do segredo. Porém, ao observarmos o v. 5, que mostra o pedido dos chefes dos filisteus a Dalila, está presente outra dimensão: descobrir em que consiste sua grande força, pois é impossível amarrá-lo sem desvendar o seu segredo. O bloco que está entre o v. 13 e o v. 20 tem uma construção mais complexa, pois o motivo da "força"14 está associado a várias Leitwörter: nāgad (contar, fazer conhecer - 4x); lēb (coração - 4x); rōšs (cabeça - 4x incluindo o texto da LXX no v. 13); e še $\underline{b} a^{\prime}$ mahllepôt (sete tranças - 3x incluindo o texto da LXX no v. 13). Outro elemento muito expressivo nos versículos deste bloco (vv. 1320) é a mudança entre o verbo da pergunta e o verbo da resposta de Sansão. Dalila pergunta como poderia "amarrá-lo" ('āsar - v. 13); Sansão responde que se deve "tecer" o seu cabelo ('ârag - v. 13). Em seguida, questionado sobre sua força, ele responde com o verbo "cortar, raspar" (gālah - v. 17). Gradativamente há uma passagem de amarrar/corda à ideia tecer/raspar/cabelo, associada à temática da "força". Contudo, mesmo existindo esses dois blocos de Leitwörter que se repetem, eles têm um eixo semântico comum: estamos sempre em torno da imagem do fio entrelaçado.

Uma repetição muito mais expressiva na perícope é a sequência de ações que estrutura esteticamente o trecho. É algo bastante comum na maneira hebraica de narrar, porém quase nunca apresenta repetições perfeitamente literais: pequenas variações de tipo estilístico - não conteudístico - são muito frequentes (STERNBERG, 1985, p. 390-393). A Bíblia Hebraica utiliza estruturas em 3 etapas (Balaão e a burra); algumas em 6 (a intercessão de Abraão - Gn 18); outras em 7 (a criação); outras em 10 (as pragas no Egito). A perícope apresenta uma típica sequência em $3+1$, onde cada repetição representa um crescendo até um ponto culminante (BLENKINSOPP, 1963, p. 65-76; SKA, 1990, p. 26-27). Por três vezes Dalila tenta descobrir o segredo da força de Sansão e por três vezes ele mente,

\footnotetext{
${ }^{14}$ É interessante observar que no primeiro pedido de Dalila a Sansão (v. 6) ela pergunta sobre sua "força". É verdade que ele responde com "me tornarei fraco", mas ele evita a resposta direta; seria enfrentar a problemática da "origem" dessa força. Por isso, o tema é abandonado em seguida, retornando somente no momento crucial da verdade (v. 17). O narrador - e não Sansão na sua resposta - é que conclui a primeira tentativa com um "porém não se conheceu a sua força".
} 
conseguindo esconder o segredo e livrar-se da armadilha montada: $1^{\text {a }}$ tentativa cordas feitas das vísceras de animais usadas para o arco e flecha (yeter - vv. 6-9); $2^{\mathrm{a}}$ tentativa - cordas vegetais novas ( $\breve{a} \underline{b} \bar{o} t-\mathrm{vv} .10-12$ ); $3^{\text {a }}$ tentativa - cabelos trançados ao tear (vv. 13-14). Entre a terceira tentativa e a quarta, a trama chega a um ponto crucial que desemboca na revelação do segredo e na captura de Sansão. Assim, enquanto as três primeiras tentativas de Dalila são frustradas, na quarta, Sansão - que parece não ter aprendido nada com as tentativas anteriores - é derrotado.

Pensamos ser importante mencionar o esquema apresentado por Block (1999, p. 456-457) em seu comentário - que servirá de base à apreciação das cenas - a partir das 4 tentativas feitas por Dalila: Dalila disse a Sansão/a ele (6.10.13.15); eis que tu zombaste de mim (-.10.13.15); e me disseste mentiras (-.10.13.-); fazme saber (6.10.13.-); em que consiste tua grande força (6.-.-.15); e como tu podes ser amarrado (6.10.13.-); então Sansão disse a ela (7.11.13.17); se... (7.11.13.17); então eu me tornarei fraco (7.11.13 [LXX $\left.\left.{ }^{15}\right] .17\right)$; e serei como um homem qualquer (7.11.13 [LXX].17); então ela disse a ele: “Os filisteus sobre ti, Sansão!" (9.12.14.20); então ele $^{16} \ldots$ (9.12.14.20); sete (7.-.13.19).

\section{Análise da Trama}

Este tópico, que é a parte mais importante deste estudo, tem por objetivo explicar a tipologia da trama e propor sua subdivisão em cenas, ou seja, de onde parte, para onde vai e como se desenvolve (SKA, 1990, p. 17-30).

\footnotetext{
${ }^{15}$ Sternberg $(1985$, p. $372 ; 384)$ chama a atenção para o fato de a LXX ter um maior desejo de harmonização do texto.

${ }^{16}$ Há uma diferença fundamental na ação de Sansão: nas duas primeiras tentativas, depois da advertência de Dalila, Sansão imediatamente "arrebentou" (nātaq) as cordas; na terceira tentativa ele "despertou" (yāqaś) e "removeu" (nāsa); na tentativa com sucesso, ele "despertou" (yāqas ) e "pensou" ('āmar). Há uma passagem de uma ação imediata a um retardamento da ação, a uma falta de ação.
} 


\subsection{Definição da trama}

\subsubsection{O programa narrativo}

Muito comumente, o narrador, depois da exposição, apresenta o "programa narrativo". É o contrato entre o autor e o leitor em vista do objetivo global da narrativa, ou seja, o narrador apresenta o problema a resolver e o plano a ser seguido. Em Jz 16,4-20, o programa narrativo aparece bastante claro no v. 5. Os chefes dos filisteus vêm a Dalila e lhe "propõem” uma missão que é descrita com dois verbos no imperativo: pātāh (imperativo Piel - persuadir, seduzir) e rā'āh (imperativo Qal - ver). Associadas ao imperativo rā'āh), o autor insere dois alvos específicos com uma construção idêntica: “...em que consiste (bammeh) sua grande força” e "como (bammeh) podemos prevalecer sobre ele”. Fazendo sequência com o imperativo, o narrador usa o weqatal do verbo 'āsar (amarrar), seguido do infinito construto Piel de 'ānāh (oprimir, subjugar) + a preposição $l^{e}$ (nuance final). Finalmente, a promessa da recompensa é construída com o yiqtol do verbo nātan (dar). Percebe-se a centralidade do verbo rā'āh com o seu duplo objeto. Tal verbo não tem o significado físico, como mera função de um órgão dos sentidos, mas o de "descobrir”, “investigar”, “conhecer”. Esse programa narrativo, como veremos, será seguido pelo narrador ao longo da trama. Assim, eis o texto: "E subiram até ela os príncipes dos filisteus e lhe disseram: 'Persuade-o e vê em que consiste a sua grande força e como poderemos prevalecer sobre ele e amarrálo, a fim de o subjugarmos; e nós te daremos cada um mil e cem siclos de prata”.

\subsubsection{Entre "anagnorisis" e "peripateia"}

Ao analisar o programa narrativo, presente no v. 5, logo percebemos que existe uma dimensão associada ao conhecimento de um segredo e outra às consequências práticas que advêm de tal conhecimento. Fazendo umabreve 
análise lexical, encontramos os seguintes elementos: rā'āh (v. 5: Qal imperativo; v. 18: wayyiqtol); uso maciço do verbo nāgad (contar) sempre ao Hiphil (vv. 6.10.13: imperativo; v. 15: perfeito negativo; v. 17: wayyiqtol; v. 18: perfeito); uso do verbo $y \bar{a} d a^{6}$ (conhecer - v. 9: Nifal perfeito; v. 20: Qal perfeito); dibēr + kāzāb (dizer mentira - vv. 10.13). Ao imperativo dos chefes dos filisteus ("Vê! Descobre!") corresponde o wayyiqtol do v. 18, depois da quarta tentativa e da descoberta do segredo: "Ela viu que...". Na primeira parte do relato, por causa das mentiras (vv. 10.13) de Sansão, "não se conheceu sua força” (v. 9). A um Sansão que conhece o segredo, que conhece a resposta para a pergunta de Dalila, corresponde um Sansão que "não sabe que o Senhor se havia separado dele" (v. 20). Todo esse processo gira em torno da raiz nāgad (contar, fazer conhecer). Nas três primeiras tentativas, mesmo depois dos repetidos imperativos ("Faz-me conhecer!" - vv. 6.10.13), Dalila é forçada a reconhecer que "tu não me fizeste conhecer..." (v. 15). O divisor de águas, porém, é o v. 16: Sansão "faz conhecer" (v. 17) e Dalila reconhece "que ele lhe havia feito conhecer todo o seu coração" (v. 18).

Sansão parece passar do conhecimento à ignorância, ao menos neste ponto concreto do relato. É bem verdade que, do ponto de vista teológico, está em jogo a própria onisciência de Deus sobre o futuro de Sansão e sua colaboração com o futuro da promessa feita ao povo de Israel, que permanece absolutamente irrevogável. À ignorância pontual de Sansão corresponde uma compreensão mais profunda do próprio desígnio de Deus para com o seu povo. Dalila, os chefes dos filisteus e o próprio leitor passam da ignorância ao conhecimento. Sternberg (1985, p. 176), por outro lado, afirma que também Sansão passa da ignorância ao conhecimento, pois agora conhece a perfídia de Dalila. Nesse sentido, o conhecimento exerce fundamentalmente uma função de poder ${ }^{17}$. Aqui está a ponte entre anagnorisis e peripateia, pois tal conhecimento é a fonte de uma mudança de situação. Porém, é claro na narração que elas não coincidem, são dois momentos bem distintos e identificáveis. A perícope estudada parece ser, portanto,

\footnotetext{
17 "When this knowledge is wrested from him, then power passes to his enemies, since they are able to use it to subdue him. In fact, both the secret of Samson's strength and the secret of his weakness lies in ownership of the knowledge of its source" (SMITH, 1997, p. 51).
} 
uma trama de "revelação", pois tudo gira em torno da descoberta de um segredo, isto é, há uma mudança de conhecimento. Contudo, a descoberta de tal segredo provoca uma mudança de situação: Sansão de homem livre, de boa visão, forte e possuidor de uma grande cabeleira, termina amarrado, cego, fraco e com os cabelos raspados. A grande novidade da trama é que seus cabelos recomeçam a crescer...

\subsubsection{Os momentos da trama}

\section{a. Exposição}

A exposição tem como função oferecer ao leitor os dados necessários para iniciar a leitura. Mesmo podendo ser adiada, em geral a exposição aparece no início do relato. Procura ambientá-lo (quando, onde), introduzir os personagens e criar certo "contrato" com o leitor para dizer por quais águas a narração vai navegar. Em Jz 16,4, como característica das exposições, o autor usa um verbo estativo e uma frase nominal. Em relação aos personagens, Sansão é tratado por “ele", pois já é conhecido do leitor a partir dos episódios anteriores. Surge como alguém apaixonado e, até certo ponto, estúpido, pois nada aprende com as três tentativas de desvendar o seu segredo feitas por Dalila. Também não há uma apresentação formal dos chefes dos filisteus, pois o leitor já conhece seus projetos traiçoeiros em relação a Sansão. O único personagem apresentado formalmente é Dalila. Muito provavelmente, para conhecer a riqueza deste personagem, podemse unir características das três etimologias que já foram propostas para o seu nome: é uma mulher estrangeira, noturna, misteriosa, apaixonante, sedutora e traiçoeira ${ }^{18}$. Sobre ela, a exposição nos dá quatro informações preciosas: a trama acontece "depois" do episódio de Gaza (16,1-3); Dalila é uma "mulher"; Sansão a “ama"; e ela mora no "Vale do Soreq". O leitor, conhecendo o inteiro ciclo de

\footnotetext{
${ }^{18}$ Recentemente Serge Frolov (2013) estudou o Livro dos Juízes e, de modo especial, o ciclo de Sansão a partir da perspectiva da sexualidade.
}

Horizonte, Belo Horizonte, v. 13, n. 38, p. 907-940, abr./jun. 2015 - ISSN 2175-5841 
Sansão, sabendo que os chefes dos filisteus estão associados a esta mulher - e que esta muito provavelmente é filisteia -, já pode imaginar o que poderá acontecer. Essas são as peças do contrato ente o autor e o leitor.

\section{b. Princípio da ação}

Há, nitidamente, uma mudança de tempo para marcar a passagem da exposição ao princípio da ação, pois no discurso direto há uma maior equivalência entre o "tempo narrado" e o "tempo da narração". Nesse momento, acende-se um vivo interesse por parte do leitor, direcionado para o "nó” que será exposto. Surge pela primeira vez o problema a ser resolvido (v. 5). Os chefes dos filisteus visitam Dalila e lhe "propõem" um acordo. O "problema” a ser resolvido gira em torno de um segredo. Podemos presumir que a resposta de Dalila foi afirmativa, já que imediatamente começa a agir.

\section{c. Complicação}

A “complicação” da perícope (vv. 6-14) é particularmente especial, pois apresenta o esquema da sequência climática, que tem como objetivo criar um alto nível de suspense e de tensão dramática em vista da tentativa com sucesso. Há um crescendo na série de repetições: cordas de arco > cordas novas > tecer o cabelo > raspar o cabelo. Na terceira tentativa, pela primeira vez, Sansão toca no tema do “cabelo", que será determinante no momento da descoberta do segredo. Por outro lado, encontra-se aí uma regressão: do mais forte (cordas de arco) ao mais frágil (fio de cabelo) e, por isso, é sugestiva a imagem de Sansão com seus cabelos completamente enredados na teia armada por Dalila.

\section{d. Clímax e "Turning point"}

Sobretudo numa narração curta como essa, é difícil distinguir esses dois elementos. Blenkinsopp ${ }^{19}$ explicando o esquema da sequência climática, fala da

\footnotetext{
${ }^{19}$ Ele propõe como princípio de unidade do ciclo de Sansão "o voto quebrado". Este é posto dentro de uma série heterogênea de episódios que tem três momentos básicos: as ligações de Sansão com as três mulheres filisteias (BLENKINSOPP, 1963, p. 73-75).
} 
última tentativa (vv. 15-22) como o clímax da perícope. Contudo, de maneira mais específica, os vv. 15 e 16 apresentam o clímax dramático: é um momento de intensa concentração de suspense: “...sua alma se angustiou para morrer”. A suspeita de Dalila em relação ao amor de Sansão e sua pressão se fazem tais que ele já não pode recuar. O v. 17a marca exatamente este "turning point" que determina toda a conclusão da narrativa, estabelecendo o início da curva descendente. É o narrador a garantir que, desta vez, Sansão não mentiu. Porém, a descoberta do segredo é somente a primeira parte da resolução do "nó".

\section{e. Resolução}

Na perícope, anagnorisis e peripateia se combinam, porém não coincidem. É verdade, contudo, que a peripateia depende do conhecimento do segredo. O v. 17b mostra a descoberta do segredo por parte de Sansão, porém o fato de revelar o segredo não implica necessariamente que Sansão vai, mais uma vez, ceder à astúcia de Dalila. Em outras palavras, podemos dizer que a situação de Sansão não muda no v. 17b, mas trata-se do início da mudança. Por isso, a necessidade dos preparativos (vv. 18-19). Nesse sentido, há uma segunda concentração de suspense em vista da realização dessa segunda etapa do plano. Por outro lado, a vinda dos chefes dos filisteus - "e levaram o dinheiro em sua mão" - é uma antecipação proléptica do sucesso do projeto. Depois da segunda etapa do plano, conhecemos um Sansão sem cabelos, sem força e "sem o Senhor" (vv. 19-20).

\section{f. Desenlace}

No desenlace ou "dénouement", o narrador apresenta o destino último de Sansão depois da resolução: é a conclusão da estória. Em geral, há uma aquietação da tensão narrativa, fazendo uma moldura com o momento anterior ao "princípio da ação". O desenlace da perícope é especialmente rico e pormenorizado: "Então 
os filisteus o agarraram e vazaram os seus olhos e o fizeram descer a Gaza e o amarraram com duas correntes de bronze" (v. 21).

A essa altura da reflexão, é preciso afrontar a problemática do v. 22. Ao contrário de muitos exegetas (cf. JONKER, 1996, p. 231), preferimos coligar o v. 22 com a narrativa anterior (VOGELS, 2006, p. 127; RIZZI, 2012, p. 357). A estória começa com Sansão e os chefes dos filisteus (vv. 4-5) e termina com os mesmos atores, só que em ordem inversa (vv. 21-22). O crescimento do cabelo de Sansão é o sinal de que a estória de Sansão não terminará naquela prisão (VOGELS, 2006, p. 128). Já tivemos oportunidade de comentar o uso do wayehî do v. 21; agora, portanto, acrescentamos outros três critérios fundamentais para coligar o v. 22 com a narrativa anterior: a) Lexical: não há nenhum verbo ou substantivo no v. 22 presente entre os vv. 23-31. Por outro lado, percebem-se claras conexões lexicais com os vv. de 4 a 21: hăālal (começar - vv. 19.22); rōšs (cabeça - vv. 13.17.19.22); gālah (raspar - vv. 17.19.22); a palavra śécār (cabelo) é substituída por um sinônimo nos versículos 13 e 19: mahlāāpāh (tranças). Isto significa que, do ponto de vista do vocabulário, o contato do v. 22 é muito mais forte com o que antecede do que com o que segue. b) Temático: os vv. 21-22 tratam da conclusão do processo de humilhação de Sansão, na prisão; de 23-31 a narrativa gira em torno do culto a Dagon e da vingança de Sansão. c) Sintático: como já explicado acima, o wayyiqtol do v. 22 dá sequência à construção wayehî + particípio (v. 21) com nuance de concomitância temporal. O v. 22, portanto, é uma informação retomada da narração precedente: pelos critérios lexical, temático e sintático, é preferível uni-lo aos vv. 4-21. Por outro lado, tal informação sinaliza uma narração subsequente, já que o fato do crescimento do cabelo determinará o retorno da

força de Sansão. Sobretudo nos vv. 19-20, há certa identificação entre cabelo-forçaSenhor. Assim, o crescimento do cabelo antecipa a restauração de sua força e, ao 
fazê-lo, antecipa em sombra a própria transformação da tragédia em comédia (VICKREY, 1981, p. 72) ${ }^{20}$.

\subsubsection{Entre Tragédia e Comédia}

Alguns estudiosos já fizeram uma comparação entre Sansão e Saul a partir dessa chave da "tragédia" e da "comédia". Exum e Whedbee (1985, p. 5-40) partem do pressuposto que, na Bíblia, a tragédia é sempre episódica e efêmera em seus efeitos. Por outro lado, uma visão globalmente cômica pode abarcar elementos trágicos da existência humana sem eliminá-los. Parece-nos ser um bom pressuposto para compreender a perícope estudada.

Diríamos que o completo ciclo de Sansão, mesmo sendo concluído com a morte do herói, é globalmente cômico: o humor e a ironia são uma constante, os jogos, as escapadas amorosas, a estrutura em repetições... O nosso episódio aparentemente apresenta tons bastante trágicos. Contudo, duas coisas apontam noutra direção: 1) a estrutura de repetições tendo por base o critério da sequência climática; a própria postura de Sansão, que joga o tempo todo, mesmo que não se trate de um simples enigma, mas de sua própria vida; 2) e o final da perícope, no v. 22, que abre claramente a perspectiva da vitória. A informação sobre o crescimento do seu cabelo (e a oração posterior) dá outra perspectiva ao episódio final (sua morte) ${ }^{21}$, bem diferente do sentido da morte de Saul, por exemplo. Como bem sintetiza Crenshaw (1974, p. 503): "A oração de Sansão não se defronta com um inflexível silêncio; ele morre em comunhão com o Deus a quem serviu à sua própria maneira". Assim, a perícope é prenúncio desse final, que é cômico em última análise, mas realista, pois não elimina os elementos trágicos da existência humana e histórica de Israel.

\footnotetext{
${ }^{20}$ Crenshaw (1974, p. 501) comenta o versículo como uma "marca de gênio" e faz um paralelo com o final da História Deuteronomista (2Rs 25,27-30): a libertação do rei Joaquin e o favor recebido na corte babilônica são presságios de esperança para o futuro do povo de Deus.

${ }^{21}$ Cf. o artigo de Rachel Harris (2012) sobre suicídio e morte na Bíblia Hebraica.
} 


\subsection{Divisão da trama em cenas}

Tentamos, a partir dos critérios dados por Ska (1988, p. 324-339) - a saber: os verbos de ação e as mudanças de tempo, de lugar e de personagens -, dividir o episódio em cenas. Assim propomos:

\subsubsection{Narração silenciosa (v. 4)}

Nesse "momento" da narração silenciosa, o narrador nos dá uma informação temporal ("Depois disso...") que conecta o nosso episódio com o anterior da prostituta de Gaza (16,1-3) e, muito provavelmente, também com o episódio da mulher timnita $(14,1)$, pois o segredo de Sansão parece ter vinculação explícita com o "voto quebrado" por meio do contato com estas três mulheres filisteias (RIZZI, 2012, p. 393). A força bruta de Sansão contrasta com a sua fraqueza em relação às mulheres estrangeiras (NAVARRO PUERTO, 1995, p. 114). O local é o Vale do Soreq (Shefelah), uma região de fronteira entre o território da tribo de Judá e o território dos filisteus. Sansão se envolve com uma mulher cujo nome é Dalila. Em teoria, Dalila (pelo nome e pela geografia) poderia ser ou israelita ou filisteia. Contudo a julgar por certa “queda” que Sansão tem pelas mulheres filisteias e pela proposta que os chefes dos filisteus lhe fazem, é muito mais provável que ela seja filisteia. Algo novo no ciclo de Sansão é o sentimento que ele nutre por essa mulher: “ele a amou” ('āhab $)$. É bem verdade que esse mesmo verbo já aparece no lamento de sua primeira mulher (Jz 14,16), mas acompanhado de um advérbio de negação. A primeira mulher é "agradável aos olhos" (14,3.7) de Sansão; a segunda, trata-se somente da relação com uma prostituta. No nosso episódio, a informação do narrador $(\mathrm{Jz} 16,4)$ é, de certo modo, confirmada por Dalila/Sansão em 16,15. 


\subsubsection{Acordo dos filisteus com Dalila (v. 5)}

Aqui começa a ação propriamente dita, que coincide também com o programa narrativo de todo o relato. Aparece um personagem coletivo novo (os chefes dos filisteus), porém caracterizado como um "tu”, já que é uma marca dos diálogos na narrativa hebraica. É extremamente alta a soma proposta pelos chefes da "Pentápolis Filisteia". Não é clara a motivação da resposta de Dalila. O importante, porém, é que ela concordou em colaborar com eles. Dalila aparece como uma mulher independente, não vinculada a nenhum homem e capaz de negociar diretamente com os filisteus (NAVARRO PUERTO, 1995, p. 115). Entre a proposta dos chefes dos filisteus e a primeira tentativa de Dalila, podemos supor certo intervalo de tempo na "estória" que serve de critério para indicar a passagem à cena seguinte.

\subsubsection{As três tentativas falidas (vv. 6-14)}

O narrador, então, apresenta as três tentativas de Dalila em desvendar o segredo de Sansão. A característica fundamental é que elas redundaram em falimento: 1) Vv. 6-9: primeira tentativa - cordas de arco feitas de intestino de animais; 2) Vv. 10-12: segunda tentativa - cordas vegetais novas; 3) Vv. 13-14: terceira tentativa - cabelos tecidos ao tear. As três tentativas falidas, como já pudemos observar, são construídas com um nítido esquema de repetições, o qual é sintetizado por Blenkinsopp (1963, p. 74) em sete passos: 1) os filisteus falam a Dalila; 2) Dalila a Sansão; 3) Sansão responde a Dalila; 4) ação de Dalila; 5) advertência: "Os filisteus sobre ti, Sansão!"; 6) ação de Sansão; 7) resultado: falimento da tentativa - não revelação do segredo.

Há, porém, algumas mudanças estilísticas, e outra que se apresenta mais séria: o tema da "força" aparece no primeiro pedido de Dalila e depois retorna 
somente na quarta tentativa. Pensamos ser o caso de uma ausência importante ou, em outras palavras, Dalila quase que de propósito "esquece” a primeira parte do pedido dos chefes dos filisteus; e Sansão, na sua resposta, "evita-o”. Tal tema retorna nos vv. 15-20 (4x) evoluindo para uma identificação com “o Senhor" (vv. 19 e 20). Parece-nos ser esse o motivo do respeito reverente em relação a tal tema: trata-se propriamente de sua origem e fonte.

As três repetições apresentam uma imagem complexa de Sansão: ele não percebe a malícia de Dalila, cai em suas armadilhas, não desperta ao ser amarrado, não se dá conta da presença de homens escondidos no quarto. Por outro lado, poder-se-ia imaginar que ele tinha consciência disso, mas queria “jogar" com aquela por quem estava apaixonado, já que tinha segurança de sua força. A resposta sobre a identidade de Sansão no episódio não é tão clara. Contudo, há uma frase de Sansão que se repete e que diz algo sobre sua autoconsciência: “...então me tornarei fraco e serei como um homem qualquer”. Significa que ele sabe que não é um homem qualquer. Por que não o é? Isso é o que procura responder a última tentativa.

\subsubsection{A última tentativa: sucesso (vv. 15-21)}

A reação de Dalila em preparação à tentativa em que logra sucesso é de maneira especial elaborada. Há uma claríssima desaceleração do ritmo. Agora, estão mais uma vez a sós Sansão e Dalila. Podemos também imaginar uma mudança de tempo. Dalila, no seu discurso, reassume as três primeiras tentativas com dois verbos: tālal (zombar) e nāgad ao negativo (não contar, não revelar). Ela põe em dúvida o sentimento que Sansão lhe diz ter. Por outro lado, reintroduz o tema da "força" como centro das atenções e faz figurar o tema do coração (lēb), entendido como o interior do ser humano, a sede das decisões, do intelecto (BURNEY, 1930, p. 382; SOGGIN, 1987, p. 253). Essa última tentativa se organiza em dois momentos: a revelação do segredo e a ação para raspar as tranças de Sansão e humilhá-lo: 
1) Vv. 15-17: reação/pressão de Dalila - revelação do segredo

Depois da reação de Dalila, o narrador apresenta um sumário da pressão feita por ela e a narração chega ao máximo da tensão dramática no final do v. 16. Sansão, angustiado ao ponto de morte, cede e revela o seu segredo. Repete-se o tema do segredo de um enigma, mas dessa vez o que está em jogo é a fonte de sua vitalidade. A força persuasiva de Dalila cresce à medida que a estória avança e o apelo ao tema do afeto é decisivo para a descoberta do segredo. A resposta de Sansão é composta de uma asserção e de uma causa, seguido de uma frase hipotética com suas consequências. Aqui acontece a primeira aproximação entre "cabelo", "força" e "Deus" e reaparece o tema da consagração de Sansão, que está presente no início do ciclo: ele é nazireu de Deus, e se tiver o cabelo raspado, perderá a sua força. O anjo do Senhor, quando anuncia o nascimento do menino, já revelou sua consagração, que deve ser preparada desde o ventre materno ( $\mathrm{Jz}$ 13,35.7). No diálogo do pai de Sansão com o anjo (Jz 13,12-14), contudo, desaparece o aspecto vinculativo em relação ao menino. O pai pergunta ao anjo "qual será a norma de conduta (mišpāt ) do menino e a sua obra". O anjo, porém, responde-lhe sobre a mãe do menino (v. 13). O menino, todavia, cresce abençoado e cheio do espírito do Senhor ( $\mathrm{Jz}$ 13,24). No inteiro ciclo, Sansão teve pouquíssima consciência e nem levou muito a sério os elementos do "voto". Ironicamente, o autor o ambienta ou nos vinhedos de Timna $(14,5)$ ou no Vale do Soreq $(16,4)$, que significa vale das vinhas escolhidas; em contato com gentios; comendo comida impura (14,8-9); e em permanente relacionamento com mulheres estrangeiras $(14,1 ; 16,1 ; 16,4)$. Na verdade, o ciclo de Sansão não nos dá a possibilidade de concluir se o nazireato de Sansão é um voto permanente e incondicional. A única certeza que resta é a sua incondicional força como provinda de Deus (JONKER, 1996, p. 260). 
O tema da força que reside nos cabelos é conhecido na história das religiões e nas tradições populares ${ }^{22}$. Sua presença aqui é interpretada por alguns como certo eco do mito solar23. Em 13,5 aparece a recomendação de não raspar a cabeleira do menino, mas não se diz que o comprimento de seu cabelo lhe daria uma força especial. Contudo, o tema da força que reside nos cabelos de Sansão é básico para a perícope e a mesma não pode ser compreendida sem esse motivo, pois é o elemento que caracteriza Sansão (PALMER, 1913, p. 32).

2) Vv. 18-21: preparativos - ação - sucesso - resultado - humilhação

A revelação do segredo não é necessariamente determinante para a vitória sobre Sansão. Nesse sentido, anagnorisis e peripateia não coincidem, mesmo que aquela esteja em função desta. No v. 18, há uma nova desaceleração no processo narrativo: é momento de preparar a ação final. Reaparecem os chefes dos filisteus e mais adiante um ajudante. Pode-se também supor uma mudança temporal. A preocupação já não é "descobrir um segredo", mas “dominar um homem forte”.

A primeira frase nos intriga. Depois de ser enganada "três vezes", Dalila "desta vez" sabe que Sansão "revelou todo o seu coração". A segurança da intuição feminina é tal que ela convence os chefes dos filisteus e os manda chamar. E estes, antecipando o desenlace, até lhe trazem o dinheiro. Dalila domina a cena: ela "vê", "manda chamar", "faz Sansão dormir", "chama um homem", "começa a oprimir Sansão". Fazendo a leitura a partir do ponto de vista dos filisteus, Dalila é a mulher madura, responsável, verdadeira, que cumpre o papel que o seu povo lhe pede, "é a verdadeira heroína da estória” (NAVARRO PUERTO, 1995, p. 117-118). É sugestiva a evolução da imagem de Sansão que dorme: na primeira e na segunda tentativa, não aparece; na terceira, ele dorme (sem especificação do lugar); na última tentativa, ele dorme "nos joelhos de Dalila". Ela o controla completamente. A

\footnotetext{
${ }^{22}$ Soggin (1987, p. 257) apresenta exemplos da cultura europeia, grega e indiana, onde a força de um herói está escondida nos seus cabelos. Havia grande difusão dessa tradição popular. Cf. também NIDITCH, (1990, p. 612).

${ }^{23}$ Burney $(1930$, p. 391) nos dá uma lista de elementos míticos presentes no ciclo de Sansão: a) o nome Sansão, conectado a šemeš (sol): um culto solar é atestado em Bet-Shemesh, região do Vale do Soreq; b) o nome Dalila, interpretado como "aquela da noite"; c) as tranças do cabelo como imagem dos raios do sol; d) o adormecer e o enfraquecer nos braços de Dalila (noite); e) o sono e a cegueira: o sol se põe; f) o girar do moinho que segue o ritmo do sol que se levanta e se põe sem parar. Contudo, parece-nos não ser o caso de insistir sobre este aspecto, pois é preferível ler o relato na perspectiva da história da relação de Israel com o seu Deus.
} 
antecipação do final do v. 19 é também importante: no discurso, Sansão ainda dorme; na estória, Dalila já começou a oprimi-lo e o narrador já confirmou o afastamento de sua força, associando-a mais uma vez ao tema do cabelo.

Sansão, desperto do sono, já não age: somente "monologa”. Há certo jogo entre o “dessa vez” de Dalila e o "das outras vezes” de Sansão. Essa já não é uma como “das outras vezes". A esse ponto, o texto apresenta outra ruptura, esta fundamental. Primeiro porque marca a saída de cena de Dalila, que desaparece no silêncio. No palco, as luzes caem sobre os filisteus que, a partir de agora, dominam e humilham Sansão. Segundo, e mais importante: aqui acontece a identificação fundamental entre "força" $\left(k \bar{o}^{a} \underline{h}\right)$ e "Senhor" $(Y H W H)$. Ele é a verdadeira fonte e origem de uma força que se expressa externamente nos fios de uma cabeleira. Todavia, é a falta de consciência de Sansão, esse "não saber" que faz desse herói um homem fraco, como qualquer um dos seres humanos, e o leva à cegueira.

O v. 21 narra o processo de humilhação de Sansão a partir de uma cadeia narrativa de wayyiqtol: 'āhaz (agarrar) > nāqar (cegar) > yārad (descer [a Gaza]) > 'āsar - amarrar). E o processo se conclui com Sansão girando o moinho na prisão. Os filisteus tiveram oportunidade de assassinar Sansão, porém preferiram humilhá-lo e conservá-lo como “troféu”. Revelam-se, então, três elementos extremamente irônicos: Sansão está preso numa cidade sem portas, arrancadas exatamente por ele $(16,3)$; aquele que incendiava os cereais dos filisteus $(15,1-5)$ agora os mói, está a serviço deles; aquele que foi vencido por uma mulher, agora realiza o trabalho típico das mulheres ${ }^{24}$. Assim, a narração volta à calma inicial, fazendo uma moldura com a situação estática do início. Porém, parece que algo está para acontecer...

\footnotetext{
${ }^{24}$ Schökel (1973, p. 224) adverte que o trabalho com o moinho era típico das mulheres, porém Sansão parece girar um moinho grande, próprio para o trabalho de um animal.
} 


\subsubsection{Versículo-ponte - visão retrospectiva e prospectiva (v. 22)}

Toda a perícope é uma pérola narrativa, porém a "intromissão" do narrador no v. 22 é de uma preciosidade máxima ${ }^{25}$ : reassume toda a narrativa anterior, mas lança luzes para o futuro, para o próximo episódio do ciclo. Assim, essa nova concentração de suspense conturba a calma e a estaticidade do final do v. 21. É um final aberto, inquietante, esperançoso... Se, durante a perícope, houve um desejo de aproximar força - cabelo - Senhor, por que não começar a pensar que algo pode mudar? O cabelo foi sempre uma intersecção entre a "força" e o "Senhor", ou seja, aponta para algo maior. Por isso, ainda que o cabelo tenha crescido, a oração de Sansão (v. 28), marcada por tantos apelativos do nome de Deus (EXUM, 1983, p. 42), é que será determinante no episódio final. Talvez, assim, o cabelo que "começa" a crescer seja um eco do já conhecido "começar" a libertar Israel (Jz $13,5)$.

\section{Conclusão}

A riqueza da construção da perícope tem muitas facetas: sequência climática (repetições), narração e discurso direto, tragédia e comédia, resolução que envolve anagnorisis e peripateia, final aberto que implica visão retrospectiva e prospectiva, variações estilísticas, riqueza sintática, relação dinâmica entre tempo narrado e tempo da narração. Porém, o elemento essencial é que ela nos obriga a uma leitura ativa. Caminhando com a narração que constrói e resolve tensões, o leitor é participante ativo do processo: ele é convidado a tecer fios e engendrar sentidos. Para além dos fios que se entrecruzam, Jz 16,4-22 nos convida a contemplar um belo tecido, "uma terceira dimensão" (SKA, 1988, p. 338).

\footnotetext{
${ }^{25}$ Crenshaw (1978, p. 501) assim se expressa: “With a single stroke of the artist's brush the ominous skies give way to the promise of brilliant sunshine; all is not lost, for hair grows back".
} 
O esquema de repetições funciona como uma estilização da realidade e a trama é uma janela aberta à vida: amor e traição, fidelidade e idolatria, percepção e cegueira, força e fraqueza. Sansão não aprende com os erros, não reconhece a fonte última de sua força. Ele é um herói, e a estória é construída com muitos elementos das tradições populares. Mas, mais do que um herói, Sansão sintetiza a história de Israel. Na expressão de Webb (1995, p. 116): "a estória de Sansão espelha a história de Israel", é um reflexo da sorte de Israel segundo as maldições de Lv 26 e Dt 28, à luz da catástrofe do exílio (RIZZI, 2012, p. 399). E assim a trama se transforma em teologia da história: tenta influenciar o presente a partir de uma leitura do passado. Sansão é muito menos um herói salvador, na linha de Barac, Gedeão ou Jefté; é, na verdade, muito mais um herói solitário e, de certo modo, até contrário ao estilo de Samuel. Não chega, contudo, a ser um herói negativo, pois sobre ele reside o Espírito do Senhor (ABADIE, 2011, p. 149; 156). Seu destino tragicômico é completamente guiado por Deus, revelando-se como sinal da própria história de Israel. Como Sansão, Israel também se deixa iludir por seu "cabelo", não reconhecendo que este é somente ícone de uma realidade indizível. Com muita probabilidade, por trás da perícope reside o tema sapiencial da mulher estrangeira como sinal da idolatria e da influência de outras culturas sobre Israel (ABADIE, 2011, p. 151). Como Sansão, Israel também se deixa enganar e seduzir pela "mulher estrangeira", é capturado, cegado, exilado, humilhado (2Rs 25,7). Como Sansão, também Israel não reconhece a presença do Senhor. Mas também como Sansão, Israel, passando pela experiência da dor, pode reconstruir a vida e começar um processo novo de libertação, pois a força e o favor de Deus são renovados nas vicissitudes paradoxais da história. E sua promessa se revela irrevogável... 


\section{REFERÊNCIAS}

ABADIE, P. Des héros peu ordinaires: théologie et histoire dans le livre des Juges. Paris: Cerf, 2011.

ALTER, R. L'arte della narrativa biblica. Brescia: Queriniana, 1990.

BARTHÉLEMY, D. Critique textuelle de l'Ancien Testament. Fribourg: Universitaires, 1982. v. 1.

BÍBLIA. Biblia Hebraica Stuttgartensia. 5. ed. ELLIGER, K.; RUDOLPH, W.; WEIL, G. E. (Ed.). Stuttgart: Deutsche Bibelgesellschaft, 1997.

BLENKINSOPP, J. Structure and style in Judges 13-16. Journal of Biblical Literature, London, v. 82, n. 1, p. 65-76, Mar. 1963.

BLOCK, D. I. Judges, Ruth. Nashville: Broadman-Holman, 1999.

BOLING, R. G. Judges. New York: Doubleday, 1975.

BURNEY, C. F. The book of Judges. 3 ed. London: Rivingtones, 1930.

CRENSHAW, J. L. The Samson saga: filial devotion or erotic attachment? Zeitschrift für die alttestamentliche Wissenschaft, Berlin, v. 86, n. 4, p. 470-504, 1974.

CRENSHAW, J. L. Samson: a secret betrayed, a vow ignored. Atlanta: John Knox, 1978.

EXUM, J. C. The theological dimension of the Samson saga. Vetus Testamentum, Leiden, v. 33, n. 1, p. 30-46, Jan. 1983.

EXUM, J. C.; WHEDBEE, J. W. Isaac, Samson and Saul: reflections on the comic and tragic visions. In: EXUM, J. C. (Ed.). Tragedy and comedy in the Bible. Decatur: Scholars Press, 1985. p. 5-40.

FROLOV, S. Sleeping with the enemy: recent scholarship on sexuality in the book of Judges. Currents in Biblical Research, New York, v. 11, n. 3, p. 308-327, Jun. 2013.

GALPAZ-FELLER, P. Samson: the hero and the man - the story of Samson (Judges 1316). New York: Peter Lang, 2006.

GRAY, J. Joshua, Judges and Ruth. London: Oliphants, 1967.

HARRIS, R. Samsom's suicide: death and the Hebrew literary canon. Israel Studies, Sede Boker, v. 17, n. 3, p. 67-91, Fall 2012.

JONKER, L. C. Exclusivity and variety: perspectives on multidimensional exegesis. Kampen: Kok Pharos, 1996. 
JOÜON, P; MURAOKA, T. A grammar of Biblical Hebrew. Roma: Gregorian and Biblical Press, 2011.

LAGRANGE, M.-J. Le livre des Juges. Paris: Lecoffre, 1903.

LONGACRE, R. E. Weqatal forms in Biblical Hebrew prose. In: BERGEN, R. D. (Ed.). Biblical Hebrew and discourse linguistics. Dallas: Summer Institute of Linguistics, 1994. p. 50-98.

VAN DER MERWE, C. H. J. Discourse linguistics and Biblical Hebrew grammar. In: BERGEN, R. D. (Ed.). Biblical Hebrew and discourse linguistics. Dallas: Summer Institute of Linguistics, 1994. p. 13-49.

MILLER, C. L. Introducing direct discourse in Biblical Hebrew narrative. In: BERGEN, R. D. (Ed.). Biblical Hebrew and discourse linguistics. Dallas: Summer Institute of Linguistics, 1994. p. 199-241.

MOORE, G. F. A critical and exegetical commentary on Judges. New York: Charles Scribner's Sons, 1901.

NAVARRO PUERTO, M. Los libros de Josué, Jueces y Rut. Barcelona: Herder; Madrid: Ciudad Nueva, 1995.

NICCACCI, A. On the Hebrew verbal system. In: BERGEN, R. D. (Ed.). Biblical Hebrew and discourse linguistics. Dallas: Summer Institute of Linguistics, 1994. p. 117-137.

NIDITCH, S. Samson as culture hero, trickster and bandit: the empowerment of the weak. Catholic Biblical Quarterly, Washington, v. 52, n. 4, p. 608-624, 1990.

PALMER, A. S. The Samson-saga and its place in the comparative religion. London: Sir Isaac Pitman and Sons, 1913.

RIZZI, G. Giudici. Milano: Paoline, 2012.

SAINT-SAËNS, C. Samson et Dalilah. Full text of "Samson and Dalilah". Opera in three acts. Text by Ferdinand Lemaire. English Version by Frederic Lyster. Disponível em: <https://archive.org/stream/samsondalilahopeoosainuoft/samsondalilahopeoosainuoft_ djvu.txt>. Acesso em: 05 abr. 2014.

SCHÖKEL, L. A. Josué y Jueces. Madrid: Cristiandad, 1973.

SKA, J.-L. Gn 22,1-19: essai sur les niveaux de lecture. Biblica, Roma, v. 69, n. 3, p. 324$339,1988$.

SKA, J.-L. Our fathers have told us: introduction to the analysis of Hebrew narratives. Roma: Pontificio Istituto Biblico, 1990. 
SKA, J.-L. De quelques ellipses dans les récits bibliques. Bibllica, Roma, v. 76, n. 1, p. 6371, 1995 .

SKA, J.-L.; SONNET, J.-P.; WÉNIN, A. L’analyse narrative des récits de l'Ancien Testament. Paris: Cerf, 1999.

SMITH, C. Samson and Delilah: a parable of power? Journal for the Study of the Old Testament, Sheffield, v. 22, n. 76, p. 45-57, Dec. 1997.

SOGGIN, J. A. Judge: a commentary. 2 ed. London: SCM, 1987.

STERNBERG, M. The poetics of Biblical narrative: ideological literature and the drama of reading. Bloomington: Indiana University, 1985.

VICKERY, J. In strange ways: the story of Samson. In: LONG, B. O. Images of Man and God: Old Testament short stories in literary focus. Sheffield: Almond, 1981. p. 58-73.

VOGELS, W. Samson: sexe, violence et religion (Juges 13-16). Otawa: Novalis, 2006.

WALTKE, B. K.; O'CONNOR, M. P. An introduction to Biblical Hebrew syntax. Winona Lake: Eisenbrauns, 1990.

WEBB, B. A serious reading of the Samson story (Judges 13-16). Reformed Theological Review, Melbourne, v. 54, n. 3, p. 110-120, 1995. 